\title{
PENGARUH PENAMBAHAN PURE SUKUN (Artocarpus communis) PADA PEMBUATAN PASTA SEGAR FETTUCINE TERHADAP DAYA TERIMA KONSUMEN
}

\author{
Siti Nasya Nurhayati ${ }^{1)}$, Mahdiyah ${ }^{1, *)}$ dan Cucu Cahyana ${ }^{1)}$ \\ 1) Program Studi Pendidikan Tata Boga, Fakultas Teknik, Universitas Negeri Jakarta \\ *) corresponding author: mahdiyah.unj@gmail.com
}

\begin{abstract}
This study aims to determine and analyze the effect of the addition of mashed breadfruit (Artocarpus communis) in the making of fresh pasta fettucine to consumer acceptance. Research conducted at the Laboratory Food Processing Culinary Education Program, Faculty of Engineering, Jakarta State University. The implementation of the research lasted until January 2017. This study used an experimental method. The sample $\mathrm{n}$ this study is fresh pasta fettucine with the addition of mashed breadfruit as much as $40 \%, 50 \%, 60 \%$. The sample was tested to 30 bit trained panelist who assess the aspect of color, flavor, taste, and texture (elasticity). Statistical analysis showed that the addition of mashed breadfruit (Artocarpus communis) in the making of fresh pasta fettucine to consumer acceptance only effected in the aspect of flavor. Based on the result of Tukey test on the aspect of flavor, the best formula suggested is an increase of 50\% addition of mashed breadfruit. This supports the research objective of optimizing the addition of breadfruit that is used.
\end{abstract}

Key words: Mashed Breadfruit, Fresh Pasta Fettucine, Consumer Acceptance

\begin{abstract}
Abstrak :
Penelitian ini bertujuan untuk mengetahui dan menganalisis pengaruh penambahan pure sukun (Artocarpus communis) pada pembuatan pasta segar fettucine terhadap daya terima konsumen. Penelitian dilakukan di Laboraturium Pengolahan Makanan Program Studi Tata Boga, Fakultas Teknik, Universitas Negeri Jakarta. Penelitian dilaksanakan hingga Januari 2017. Penelitian ini menggunakan metode eksperimen. Sampel dalam penelitian ini adalah pasta segar fettucine dengan penambahan pure sukun sebanyak $40 \%, 50 \%$, dan $60 \%$ yang kemudian diujikan kepada 30 panelis agak terlatih yang menilai aspek warna, aroma, rasa, dan tekstur (kekenyalan). Hasil uji statistik menunjukkan bahwa penambahan pure sukun pada pembuatan pasta segar fettucine hanya mempengaruhi aspek aroma. Berdasarkan hasil uji Tukey pada aspek aroma, formula paling disukai konsumen dan disarankan adalah penambahan pure sukun sebanyak 50\%. Hal ini mendukung tujuan penelitian yaitu optimalisasi penambahan sukun yang digunakan.
\end{abstract}

Kata Kunci: Pure Sukun, Pasta Segar Fettucine, Daya Terima Konsumen 


\section{PENDAHULUAN}

Pasta adalah salah satu jenis makanan pokok dari kelompok mie yang berasal dari Eropa dan khususnya sudah lama banyak dikembangkan di daerah Italia. menurut International Pasta Organization (IPO) dalam Global Trade Information Services, Indonesia merupakan salah satu negara dengan tingkat eskpor terhadap produk pasta dengan jumlah yang meningkat selama tahun 2011-2013 yaitu sebanyak $7003 \mathrm{~kg}$ per kapita. Hal ini membuat peluang untuk pengembangan produk pasta menjadi semakin terbuka.

Menurut Cahyana dan Artanti (2009), Pasta dibagi menjadi dua jenis yaitu pasta kering dan pasta segar. Pasta kering yaitu pasta yang sudah dibentuk lalu melalui proses pengeringan. Sedangkan pasta segar yaitu jenis adonan pasta yang setelah dicetak langsung melalui proses pemasakan atau tidak melewati proses pengeringan terlebih dahulu. Salah satu pasta yang sudah banyak dikenal masyarakat adalah fettucine. Fettucine merupakan salah satu jenis pasta yang berukuran panjang dan agak lebar sehingga biasa juga disebut dengan mie pipih atau gepeng.

Menurut Croce (2000), fettucine dibuat dari campuran tepung terigu dengan telur yang diuleni hingga kalis lalu melalui tahap pemipihan hingga ketebalan $1 \mathrm{~mm}$ dan dicetak melalui pasta machine.

Buah sukun merupakan salah satu produk pangan lokal musiman yang kaya akan kandungan karbohidrat. Sukun sangat potensial atau memiliki peluang yang besar untuk menopang kebutuhan sumber pangan karena mempunyai kandungan gizi dan sumber kalori yang tinggi. Pengembangan produk dari buah sukun secara intensif juga akan berkontribusi terhadap upaya yang mendukung ketahanan pangan nasional.

Karena buah sukun bersifat musiman atau tidak selalu ada di pasaran, maka perlu dilakukan proses untuk memperpanjang umur simpan buah sukun tersebut. Salah satu proses yang telah dilakukan oleh Nurulita Rizka (2014) untuk mampu menyiapkan buah sukun sebagai buah musiman dapat tersedia sepanjang waktu dengan cara dikeringkan/dibuat tepung kemudian disubstitusikan terhadap pembuatan pasta segar fettucine. Namun prosesnya cukup panjang dan berpotensi juga kehilangan zat gizi buah sukun. Menghindari hal tersebut, perlu dilakukan inovasi dan teknik praktis.

Proses atau teknik lain yang lebih sederhana dalam pemanfaatan sukun adalah dengan cara membuatnya menjadi pure. Pembuatan pure sukun jauh lebih sederhana dari pembuatan tepung sukun karena hanya melewati satu jenis teknik pengolahan yaitu teknik steam blanching. Selain itu, prosesnya lebih tepat dan mudah untuk dilakukan pada industri berskala rumah tangga.

Penambahan pure pada pembuatan pasta segar fettucine ini diharapkan dapat berguna sebagai salah satu pengembangan produk dari buah sukun. Selain itu, penelitian ini diharapkan dapat meningkatkan nilai ekonomis pada buah sukun sebagai pangan lokal fungsional dengan aplikasi terhadap produk Internasional.

\section{METODE PENELITIAN}

Pada penelitian pendahuluan, dilakukan eksperimen awal yang bertujuan untuk menentukan formula dasar pembuatan pasta segar fettucine, pembuatan pure sukun, dan perhitungan kadar air. Kemudian dilanjutkan kepada penelitian lanjutan untuk mencari persentase terbaik penambahan pure sukun pada pembuatan pasta segar fettucine. Penelitian ini dilakukan di Laboratorium Pengolahan Makanan Program Studi Tata Boga, Fakultas Teknik, Universitas Negeri Jakarta. Pengujian daya terima konsumen dilakukan pada aspek warna, aroma, rasa, dan tekstur (kekenyalan) kepada 30 orang panelis agak terlatih.

Penelitian ini melibatkan dua variabel yaitu variabel bebas dan variabel terikat. Variabel bebas pada penelitian ini yaitu penambahan pure sukun sebesar $40 \%, 50 \%, 60 \%$ pada pembuatan pasta 
segar Fettucine. Variabel terikat dalam penelitian ini yaitu tingkat kesukaan terhadap pasta segar Fettucine dengan penambahan pure sukun.

Pada penelitian ini dilakukan proses pembuatan pasta segar fettucine dengan persentase penambahan pure sukun yang berbeda. Perbaikan formula dilakukan dalam mengupayakan optimalisasi penggunaan sukun yang ditambahkan, serta menghasilkan pasta segar fettucine yang baik, sesuai standar yang diharapkan. Analisis data yang digunakan adalah analisis uji friedman, karena data yang diperoleh dari penelitian ini merupakan data jenis kategori dan lebih tepat menggunakan analisis non parametrik.

\section{HASIL DAN PEMBAHASAN}

Keseluruhan dalam uji coba pada penelitian ini bertujuan untuk mengetahui dan menganalisis pengaruh penambahan pure sukun (Artocarpus communis) pada pembuatan pasta segar fettucine terhadap daya terima konsumen. Penilaian dilakukan oleh 30 panelis agak terlatih terhadap daya terima konsumen produk pasta segar fettucine dengan penambahan pure sukun meliputi aspek warna, aroma, rasa, dan tekstur (kekenyalan), dinilai menggunakan skala penilaian yang meliputi rentangan sangat suka, suka, agak suka, tidak suka, dan sangat tidak suka. Kemudian hasilnya disimpulkan secara deskriptif dan diuji melalui hipotesis statistik.

Berdasarkan hasil uji deskriptif, rata-rata penilaian panelis terhadap aspek warna pasta segar fettucine dengan penambahan pure sukun sebanyak $40 \%$ adalah 4,03 yang menunjukan rentangan kategori suka. Sedangkan penilaian panelis terhadap aspek warna pasta segar fettucine dengan penambahan pure sukun sebanyak 50\% adalah 4,07 yang menunjukan rentangan kategori suka. Kemudian penilaian panelis terhadap aspek warna pasta segar fettucine dengan penambahan pure sukun sebanyak $60 \%$ adalah 4,00 yang menunjukan rentangan kategori suka. Nilai rata-rata pada aspek warna pasta segar fettucine dengan penambahan pure sukun menunjukan bahwa formula dengan penambahan pure sukun sebanyak 50\% adalah yang paling disukai oleh konsumen dengan nilai rata-rata 4.07 dengan rentang kategori suka.

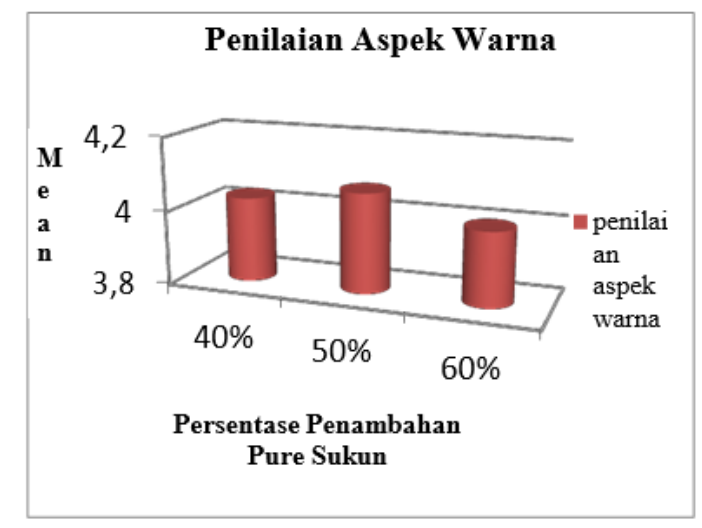

Gambar 1. Hasil Uji Organoleptik Daya Terima Konsumen Aspek Warna

Rata-rata penilaian panelis terhadap aspek aroma pasta segar fettucine dengan penambahan pure sukun sebanyak 40\% adalah 3,90 yang menunjukan rentangan kategori agak suka mendekati suka. Rata-rata penilaian panelis terhadap aspek aroma pasta segar fettucine dengan penambahan pure sukun sebanyak $50 \%$ adalah 3,47 yang menunjukkan rentangan kategori agak suka. Sedangkan rata-rata penilaian panelis terhadap aspek aroma pasta segar fettucine dengan penambahan sukun 60 $\%$ adalah 3,00 yang menunjukkan bahwa formula dengan penambahan pure sukun sebayak $40 \%$ adalah yang paling disukai oleh konsumen dengan nilai rata-rata 3,90 dengan rentang kategori agak suka mendekati suka. 


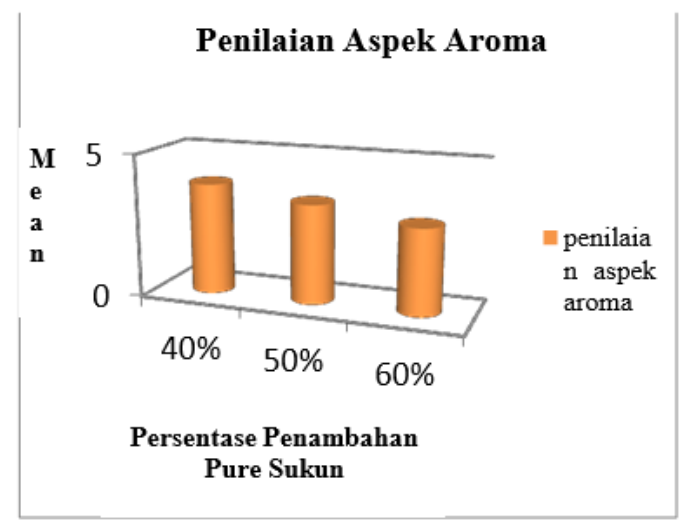

Gambar 2. Hasil Uji Organoleptik Daya Terima Konsumen Aspek Aroma

Rata-rata penilaian panelis terhadap aspek rasa pasta segar fettucine dengan penambahan pure sukun sebanyak $40 \%$ adalah 3,77 yang menunjukan rentangan kategori agak suka mendekati suka. Sedangkan penilaian panelis terhadap aspek rasa pasta segar fettucine dengan penambahan pure sukun sebanyak 50\% dan $60 \%$ adalah 3,87 yang menunjukan rentangan kategori agak suka mendekati suka. Nilai rata-rata pada aspek rasa pasta segar fettucine dengan penambahan pure sukun menunjukan bahwa formula dengan penambahan pure sukun sebanyak $50 \%$ dan $60 \%$ adalah yang paling disukai oleh konsumen dengan nilai rata-rata yang sama yaitu 3.87 dengan rentang kategori agak suka mendekati suka.

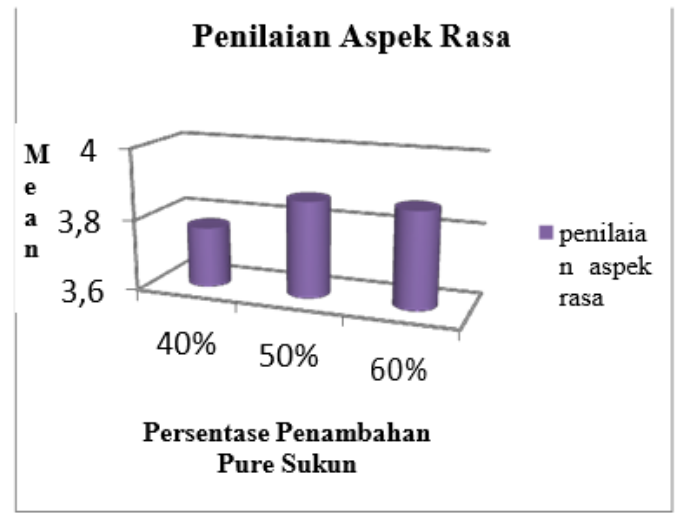

Gambar 3. Hasil Uji Organoleptik Daya Terima Konsumen Aspek Rasa

Sedangkan rata-rata penilaian panelis terhadap aspek tekstur (kekenyalan) pasta segar fettucine dengan penambahan pure sukun sebanyak 40\% adalah 3,77 yang menunjukan rentangan kategori agak suka mendekati suka. Rata-rata penilaian panelis terhadap aspek tekstur (kekenyalan) pasta segar fettucine dengan penambahan pure sukun sebanyak 50\% adalah 3,80 yang menunjukan rentangan kategori agak suka mendekati suka. Sedangkan rata-rata penilaian panelis terhadap aspek tekstur (kekenyalan) pasta segar fettucine dengan penambahan pure sukun sebanyak $60 \%$ adalah 3,60 yang menunjukan rentangan kategori agak suka mendekati suka. Nilai rata-rata pada aspek tekstur pasta segar fettucine dengan penambahan pure sukun menunjukan bahwa formula dengan penambahan pure sukun sebanyak $50 \%$ adalah yang paling disukai oleh konsumen dengan nilai rata-rata 3.80 dengan rentang kategori agak suka mendekati suka. 


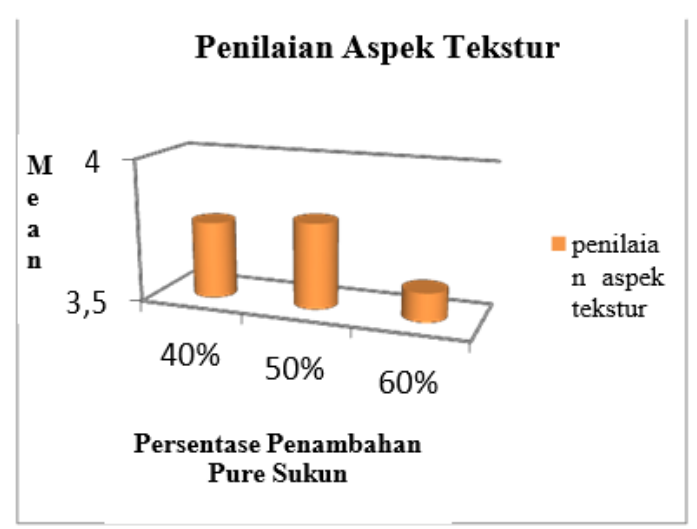

Gambar 4. Hasil Uji Organoleptik Daya Terima Konsumen Aspek Tekstur (kekenyalan)

Berdasarkan hasil uji hipotesis statistik, penambahan pure sukun pada pembuatan pasta segar fettucine hanya memiliki pengaruh pada aspek aroma. Menurut Pitojo (1982), sukun memiliki aroma yang khas dan spesifik. Aroma yang dihasilkan bergantung kepada jenis dan tingkat kematangan sukun yang digunakan. Dalam penelitian ini, tingkat kematangan sukun yang digunakan adalah sukun tua. Maka semakin banyak persentase penambahan pure pada adonan pasta, akan semakin kuat aroma yang ditimbulkan.

Berdasarkan hasil dari empat aspek yang dinilai, produk yang paling disukai oleh konsumen dan direkomendasikan adalah penambahan pure sukun sebanyak $50 \%$ pada pembuatan pasta segar fettucine. Hal ini terkait dengan optimalisasi penambahan sukun yang digunakan

\section{SIMPULAN}

Berdasarkan hasil analisis uji hipotesis, terdapat pengaruh penambahan pure sukun pada pembuatan pasta segar fettucine terhadap daya terima konsumen pada aspek aroma.

\section{DAFTAR PUSTAKA}

Cahyana, Cucu dan Artanti, Guspri Devi. 2009. Buku Pintar Masak Hidangan Kontinental. Jakarta: Gramedia Pustaka.

Croce, Julia Della. 2000. Pasta. Singapore: Colourscan

Pitojo, S. 1992. Budidaya Sukun. Yogyakarta: Penerbit Kanisisus.

Rizka, Nurulita 2014. Pengaruh Subtitusi Tepung Sukun (Artocarpus communis) terhadap Daya Terima Pasta Segar Fettucini [Skripsi]. Jakarta : UNJ. 